\title{
Coating of magnetite with mercapto modified rice hull ash silica in a one-pot process
}

\author{
Nuryono Nuryono ${ }^{1 *}$, Nur Mutia Rosiati ${ }^{1}$, Bambang Rusdiarso ${ }^{1}$, Satya Candra Wibawa Sakti ${ }^{2}$ and Shunitz Tanaka ${ }^{2,3}$
}

\begin{abstract}
In this research, mercapto-silica coated magnetite $\left(\mathrm{Fe}_{3} \mathrm{O}_{4}-\mathrm{SiO}_{2}-\mathrm{SH}\right)$ has been prepared in aqueous solution through a simple approach so called a one-pot process. The $\mathrm{Fe}_{3} \mathrm{O}_{4}-\mathrm{SiO}_{2}-\mathrm{SH}$ was prepared in nitrogen condition by mixing magnetite, 3-mercaptopropyltrimethoxysilane (MPTMS), and sodium silicate $\left(\mathrm{Na}_{2} \mathrm{SiO}_{3}\right)$ solution extracted from rice hull ash, and adjusting the $\mathrm{pH}$ of 7.0 using hydrochloric acid. The residue was washed with deionized water, dried at $150^{\circ} \mathrm{C}$ and separated with an external magnetic field. In that work, the volume of MPTMS and $\mathrm{Na}_{2} \mathrm{SiO}_{3}$ was varied and the total amount of Si represented as silica was kept constant. Characters of the material including the functional group presence, the structure, the porosity, the morphology and stability toward various solvents were identified and evaluated. Results of characterization indicated that mercapto-silica has been coated magnetite particle with a simple one-pot process. Coating mercapto-silica on magnetite increases particle size, surface area, and chemical stability. Additionally, $\mathrm{Fe}_{3} \mathrm{O}_{4}-\mathrm{SiO}_{2}-\mathrm{SH}$ also shows high stability toward various organic solvents. The magnetic property of magnetite does not change after coating and the addition of nonmagnetic material still gives high value of maximum saturation magnetization. The presence of mercapto groups effective for interaction with heavy metal ions, the high chemical stability without removing the magnetic property promises the prospective application of $\mathrm{Fe}_{3} \mathrm{O}_{4}-\mathrm{SiO}_{2}-\mathrm{SH}$ in the future such as for separation and removal of heavy metal ions from aquatic environments.
\end{abstract}

Keywords: Magnetite; Silica; Rice; Coating; One-pot process

\section{Introduction}

Among the magnetic materials, iron oxides play a major role in many areas of chemistry, physics and material sciences. In particular, magnetic iron oxides such as magnetite $\left(\mathrm{Fe}_{3} \mathrm{O}_{4}\right)$ and maghemite $\left(\gamma-\mathrm{Fe}_{2} \mathrm{O}_{3}\right)$ have been investigated intensively for environmental and bioapplications (Daniel-da-Silva et al. 2007, 2008; Rebolledo et al. 2008; Hong et al. 2008; Li et al. 2007). Magnetite based materials with high magnetic characteristic are very effective as adsorbents for heavy metal ions removal. Superparamagnetic particles adhered to the target can be removed very quickly from a matrix using a magnetic field, but they do not retain their magnetic properties when the field is removed (Yantasee et al. 2007). However, it should be pointed out that uncoated magnetic nanoparticles are highly susceptible to oxidation when exposed to atmosphere and also susceptible to leaching under acidic

\footnotetext{
*Correspondence: nuryono_mipa@ugm.ac.id

'Department of Chemistry, Faculty of Mathematics and Natural Sciences, Universitas Gadjah Mada, Yogyakarta 55281, Indonesia

Full list of author information is available at the end of the article
}

conditions (Ren et al. 2008; Mahmoudi et al. 2011). In addition to convenient magnetic properties and low toxicity and price, $\mathrm{Fe}_{3} \mathrm{O}_{4}$ exhibit high surface to volume ratios, depending on the particle size, which associated to their ability for surface chemical modification can enhance the capacity for heavy metal adsorption in water treatment processes.

Inorganic polymers, such as silica, have been used as stabilizing agents for iron oxide and the silica coating has attractive properties including high biocompatibility (Mahmoudi et al. 2011), adsorption capacity, acid-base properties, insolubility in most solvents, and chemical and thermal stability (Yang 2003). In addition, silica can be grafted with a variety of functional groups, leading to considerable enhancement of their surface properties. Surface modification achieved by the attachment of inorganic shells or/and organic molecules not only stabilizes the nanoparticles, eventually preventing their oxidation, but also provides specific functionalities that can be selective for ion uptake. This system also has several advantages compared with conventional and other adsorbents in that

\section{实}


the process does not generate secondary waste and the materials involved can be recycled and facilely used on an industrial scale. Furthermore, the magnetic particles can be tailored to fix and separate metal species in water, wastes, or slurries (Ren et al. 2008; Ngomsik et al. 2006; Li et al. 2008; $\mathrm{Hu}$ et al. 2005; Yavuz et al. 2006; Hai et al. 2005; Chang and Chen 2005; Liu et al. 2008; Zhou et al. 2009).

Modification of silica coated magnetite may be carried out into two steps namely coating silica on magnetite and functionalization on the silica coated magnetite (Lin et al. 2011; Shishehbore et al. 2011). The latter step is conducted by reacting silanol groups on the silica surfaces with organic compounds contaning silane groups at a high temperatur and in water free solvent to prevent hydrogen bonding that may marker the silanol groups. Nowaday, that non-green process has to be avoid. As the silica sources, organosilane agents such as tetraethoxyorthosilane (TEOS) are normally used (Yang et al. 2009; Pang et al. 2012). Using this precursor, two steps (hydrolysis and condensation) are involved in silica gel formation. However, using sodium silicate solution as the precursor, addition of acid to the solution results in the silica gel formation without hydrolysis step as reported by Lin et al. (2011). Sodium silicate that may be produced by treating rice hull ash with sodium hydroxide has been reported as precursor for preparation of ionic imprinting amino modified silica (Sakti et al. 2013), and sulfonato modified silica (Azmiyawati et al. 2012; Sulastri et al. 2011). Rice hull ash is a solid waste of agricultural products potential as row material for preparation of new silica based materials due high content of silica (80-90\%) (Sakti et al. 2013).

This paper reports a simple and green approach of coating magnetite with mercapto modified silica in aqueous solution using sodium silicate solution made of rice hull ash as the precursor and 3-mercaptopropyltrimethoxysilane as the mercapto group source. Additionally, chemical reactions that occur in the aqueous solution during coating process are proposed, and the effect of coating on the magnetite properties and stability toward various types of solvents are evaluated.

\section{Materials and methods Materials}

Chemicals used included $\mathrm{FeCl}_{2} \cdot 4 \mathrm{H}_{2} \mathrm{O}, \mathrm{FeCl}_{3} \cdot 6 \mathrm{H}_{2} \mathrm{O}, \mathrm{HCl}$ $37 \%$, and $\mathrm{NH}_{4} \mathrm{OH} 25 \%$ supplied from Merck as receipted without any prior treatment for preparation of magnetite $\left(\mathrm{Fe}_{3} \mathrm{O}_{4}\right)$, and commercial $\mathrm{Fe}_{3} \mathrm{O}_{4}$ from Aldrich used for a control material. For coating the magnetite was used $\mathrm{Na}_{2} \mathrm{SiO}_{3}$ solution $\left(13 \% \mathrm{SiO}_{2}\right)$ produced from treatment of rice hull ash and mercaptopropyltrimethoxysilane (MPTMS) from Merck.

\section{Synthesis of magnetite}

Magnetite, $\mathrm{Fe}_{3} \mathrm{O}_{4}$, was prepared using a simple chemical co-precipitation method reported anywhere. Typically, $2.0 \mathrm{~g}$ of $\mathrm{FeCl}_{2} \cdot 4 \mathrm{H}_{2} \mathrm{O}$ and $5.2 \mathrm{~g}$ of $\mathrm{FeCl}_{3} \cdot 6 \mathrm{H}_{2} \mathrm{O}$ were dissolved in $1 \mathrm{~mL}$ aqueous $\mathrm{HCl}(37 \%)$. The $\mathrm{FeCl}_{2} \cdot 4 \mathrm{H}_{2} \mathrm{O}$ and $\mathrm{FeCl}_{3} \cdot 6 \mathrm{H}_{2} \mathrm{O}$ aqueous solution was then added rapidly with $200 \mathrm{~mL}$ of deionized water and the solution was continuously sonificated under nitrogen for $1 \mathrm{~h}$. Upon adding an aqueous $\mathrm{NH}_{4} \mathrm{OH}$ solution $(25 \%, 15 \mathrm{~mL})$, a distinctive black precipitate of $\mathrm{Fe}_{3} \mathrm{O}_{4}$ was formed immediately and the precipitate was kept overnight in a room temperature. The $\mathrm{Fe}_{3} \mathrm{O}_{4}$ was isolated and purified by centrifugation and then washed with water three to four times to remove excess $\mathrm{NH}_{4} \mathrm{OH}$ solution. The magnetite resulted was dried in an oven at $80^{\circ} \mathrm{C}$ for $2 \mathrm{~h}$. The analog work was carried out with mixing technique of mechanical stirring.

\section{Coating magnetite with mercapto modified silica}

About $0.5 \mathrm{~g}$ of freshly prepared $\mathrm{Fe}_{3} \mathrm{O}_{4}$ dispersed in $1 \mathrm{~mL}$ of $\mathrm{HCl}$ solution was added with certain volume of sodium silicate solution, MPTMS and deionized water; hence the total volume of the solution was $6 \mathrm{~mL}$. The mixture then was added with solution of $\mathrm{HCl} 1 \mathrm{M}$ or $\mathrm{NH}_{4} \mathrm{OH} 1 \mathrm{M}$ drop wise to reach the $\mathrm{pH}$ of 7.0. The resulting precipitate was separated with an external magnet, washed with deionized water and dried at $80^{\circ} \mathrm{C}$ for $2 \mathrm{~h}$. The mole ratio of $\mathrm{SiO}_{2}$ in sodium silicate solution to MPTMS was varied as presented in Table 1.

\section{Characterization of products \\ Characterization with fourier transform infrared (FT-IR) spectrophotometry}

About $0.5 \mathrm{mg}$ of product was homogenized with $200 \mathrm{mg}$ of $\mathrm{KBr}$ powder and was converted into a pellet form with 2000 psi in pressure. The pellet was put in a sample cell and the absorbance was measured at a wave number range of $300-4000 \mathrm{~cm}^{-1}$.

\section{Elemental analysis}

The content of elements $(\mathrm{C}, \mathrm{H}, \mathrm{N})$ was determined with a Yanaco CHN CORDER MT-6 Elemental Analyzer, and a Dionex Ion Chromatography was used to analyze the content of sulfur.

\section{Table 1 Variation of the coating material amount}

\begin{tabular}{lcc}
\hline Product & \multicolumn{2}{c}{ Volume/amount of coating agents } \\
\cline { 2 - 3 } & $\mathrm{Na}_{\mathbf{2}} \mathrm{SiO}_{\mathbf{3}}$ ( $\mathbf{m L} / \mathbf{m o l e ~ S i O}_{\mathbf{2}}$ ) & MPTMS (mL/mole) \\
\hline $\mathrm{Fe}_{3} \mathrm{O}_{4}-\mathrm{SH}$ & $0.0 / 0.0$ & $1.27 / 6.8$ \\
$\mathrm{Fe}_{3} \mathrm{O}_{4}-\mathrm{SiO}_{2}-\mathrm{SH}(25: 75)$ & $1.5 / 1.7$ & $0.95 / 5.1$ \\
$\mathrm{Fe}_{3} \mathrm{O}_{4}-\mathrm{SiO}_{2}-\mathrm{SH}(50: 50)$ & $3.0 / 3.4$ & $0.63 / 3.4$ \\
$\mathrm{Fe}_{3} \mathrm{O}_{4}-\mathrm{SiO}_{2}-\mathrm{SH}(75: 25)$ & $4.5 / 5.1$ & $0.32 / 1.7$ \\
$\mathrm{Fe}_{3} \mathrm{O}_{4}-\mathrm{SiO}_{2}$ & $6.0 / 6.8$ & $0.00 / 0.0$ \\
\hline
\end{tabular}


Identification of structure with X-ray diffraction (XRD)

In this characterization, the sample was grounded and put in a sample cell and analyzed with XRD. $\mathrm{Cu} \mathrm{k}_{\alpha}$ radiation from $40 \mathrm{kV}$ and $30 \mathrm{~mA}$ was applied to the sample with a $2 \theta$ range of $5-70^{\circ}$ (scan speed of $5^{\circ} / \mathrm{min}$ ).

\section{Identification of morphological products}

The morphologies of all products were examined using a transmission electron microscopy (TEM) (JEM 1400) with $120 \mathrm{kV}$ power, and frame size $1024 \times 1024$ pixel.

\section{Porosity analysis}

The Brunauer-Emmett-Teller (BET) surface area analysis was conducted using the nitrogen adsorption-desorption method (GSA. type NOVA 1200) with degassing temperature of $300^{\circ} \mathrm{C}$ for $3 \mathrm{~h}$.

\section{Measurement of magnetization values}

The magnetization values of the products were identified using vibrating sample magnetometer (Oxford) at the maximum external magnetic field of 1.2 Tesla at $25^{\circ} \mathrm{C}$.

\section{Evaluation of product stability toward acid and organic solvents}

Resulted product $(0.5 \mathrm{~g})$ was mixed with $15 \mathrm{~mL}$ of $\mathrm{HCl}$ solution $1 \mathrm{M}$, shaked for $5 \mathrm{~min}$ and kept in a room temperature. From the mixture, $1 \mathrm{~mL}$ of the substrate was collected in one day interval for 5 days, and analyzed the content of dissolved iron with atomic absorption spectrophotometry. Additional work was carried out to examine the stability of the product by dispersing $10 \mathrm{mg}$ of coated silica in $50 \mathrm{~mL}$ various solvents and stirring the dispersion for $1 \mathrm{~min}$.

\section{Results and discussion}

\section{Effect of mixing techniques on magnetite character}

Addition of $\mathrm{NH}_{4} \mathrm{OH}$ solution to a mixture of $\mathrm{Fe}^{2+}$ and $\mathrm{Fe}^{3+}$ solutions leads to form back magnetite precipitate. The mole ratio of $\mathrm{Fe}^{2+}$ to $\mathrm{Fe}^{3+} 2: 1$ is needed to fulfill the stoichiometric reaction as presented in Eq. (1).

$$
\mathrm{Fe}^{2+}{ }_{(\mathrm{aq})}+2 \mathrm{Fe}^{3+}{ }_{(\mathrm{aq})}+8 \mathrm{OH}^{-}{ }_{(\mathrm{aq})} \rightarrow \mathrm{Fe}_{3} \mathrm{O}_{4(\mathrm{~s})}+4 \mathrm{H}_{2} \mathrm{O}_{(\mathrm{l})}
$$

Oxidation of $\mathrm{Fe}^{2+}$ to $\mathrm{Fe}^{3+}$ in magnetite may occur easily in the presence of oxygen; hence, free oxygen condition by flowing nitrogen may prevent oxidation reaction as expressed in Eq. (2).

$$
4 \mathrm{Fe}_{3} \mathrm{O}_{4(\mathrm{~s})}+\mathrm{O}_{2(\mathrm{~g})}+18 \mathrm{H}_{2} \mathrm{O}_{(\mathrm{l})} \rightarrow 12 \mathrm{Fe}(\mathrm{OH})_{3(\mathrm{~s})}
$$

One of factors influencing the characters of magnetite is stirring technique during co-precipitation process. In this work, the synthesis of magnetite was carried out with two stirring techniques namely mechanical and ultrasonic ones. The yield of magnetite materials synthesized through both stirring techniques is presented in Table 2. From Table 2 can be seen that ultrasonic technique gives the yield percentage of magnetite higher than the mechanic one due to effectiveness of interaction between $\mathrm{Fe}^{2+} / \mathrm{Fe}^{3+}$ with $\mathrm{OH}^{-}$to form hydroxides.

The success of magnetite synthesis may be shown from the XRD pattern (Figure 1), in which the peaks of synthesized $\mathrm{Fe}_{3} \mathrm{O}_{4}$ appear at the similar $2 \theta$ to those of commercial one. In the commercial magnetite $\left(\mathrm{c}-\mathrm{Fe}_{3} \mathrm{O}_{4}\right)$ is observed a highest peak at $35.48^{\circ}$ of space index [311]. This index peak also appears in magnetite synthesized through both mechanical $\left(\mathrm{m}-\mathrm{Fe}_{3} \mathrm{O}_{4}\right)$ and ultrasonic $\left(\mathrm{u}-\mathrm{Fe}_{3} \mathrm{O}_{4}\right)$ techniques. However, the peak intensity indicating the crystalline level is different with the order of $\mathrm{c}-\mathrm{Fe}_{3} \mathrm{O}_{4}>$ $\mathrm{u}-\mathrm{Fe}_{3} \mathrm{O}_{4}>\mathrm{m}-\mathrm{Fe}_{3} \mathrm{O}_{4}$. Evaluation of index peak [311] at $2 \theta \sim 35.5$, several parameters of crystal including interspaces distance (d), lattice parameter (a), peak intensity (I) and average crystallite diameter $\left(\overline{\mathbf{D}}_{\text {XRD }}\right)$ have been calculated and presented in Table 3.

Table 3 shows that $\mathrm{m}-\mathrm{Fe}_{3} \mathrm{O}_{4}$ gives peak intensity lower and the crystallite size represented by $\overline{\mathrm{D}}_{\mathrm{XRD}}$ smaller than $\mathrm{u}-\mathrm{Fe}_{3} \mathrm{O}_{4}$. Energy of ultrasonic wave improves effectiveness of stirring, homogenous dispersion and results in the small size crystallite. Higher stirring rate means larger energy transfer to crystallite and resulting in smaller sizes. Yang et al. (2009) reported that single phase formation of magnetite with sonochemical technique takes time only $1 \mathrm{~h}$ and $16 \mathrm{~h}$ is needed if mechanical technique is applied.

In conclusion, the use of ultrasonic wave energy probable may improve homogeneity of the mixture and effectiveness of contact between reactant particles to form precipitate of $\mathrm{Fe}(\mathrm{II}) / \mathrm{Fe}(\mathrm{III})$ hydroxide, as well as crystalline structure. Therefore, magnetite synthesized with ultrasonic technique was used for the further experiments.

\section{Characters of mercapto-silica coated magnetite}

Coating of magnetite with silica and mercapto groups was conducted in aqueous solution. It involved a gelation process of silica followed with attachment of mercapto groups from MPTMS through one sol-gel reaction in the same process. The method was chosen since it offers benefits such as organic solvent free, simple and occurs at a room temperature. Functionalization of mercapto groups on silica modified magnetite at higher temperature may decompose MPTMS as the mercapto source before attachment of

Table 2 Yield of magnetite synthesized with two stirring techniques

\begin{tabular}{lcc}
\hline Mixing & \multicolumn{2}{c}{ Yield } \\
\cline { 2 - 3 } Technique & $\mathbf{( g )}$ & (\%) \\
\hline Mechanic & 2.19 & 94.4 \\
Ultrasonic & 2.30 & 99.1 \\
\hline
\end{tabular}




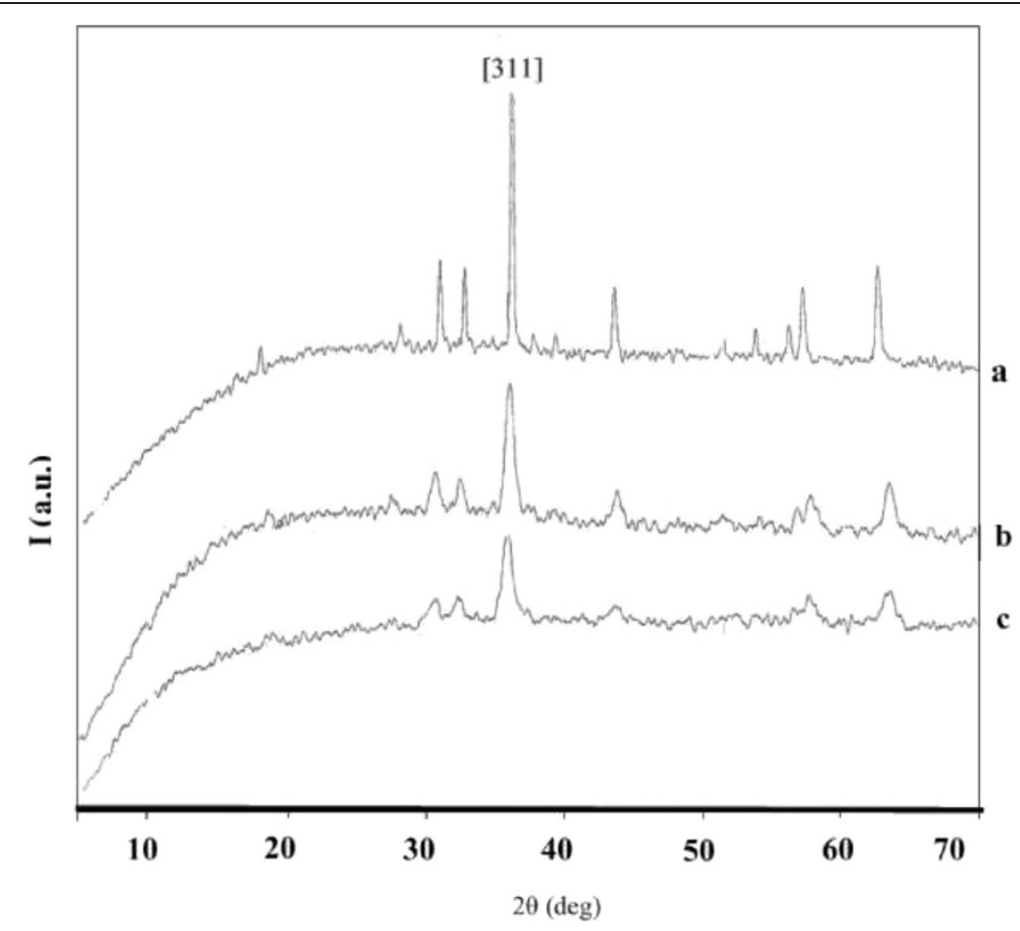

Figure 1 XRD patterns of (a) commercial magnetite, (b) magnetite synthesized with ultrasonic and (c) mechanical techniques.

the functional groups on the silica surface occurs. In this work, coating was carried out by varying the amount ratio of sodium silicate to MPTMS at constant weight of magnetite and the results can be seen in Table 4 .

Table 4 shows that washing decreases the weight of products, except for $\mathrm{Fe}_{3} \mathrm{O}_{4}$ - $\mathrm{SH}$ where sodium silicate solution was not used. Sodium chloride may be produced from reaction between sodium silicate and $\mathrm{HCl}$. This byproduct may be trapped in the coated magnetite as impurity. Washing with deionized water may dissolve that salt and may improve the purity of the coated magnetite. Therefore, by using sodium silicate as the silica source, washing of the precipitate is important step to find the coated magnetite with higher purity. By assumption no magnetite loosing during coating, the weight fraction of silica and mercapto group can be calculated and presented in the last column of Table 4.

\section{Elemental analysis}

Analysis of three elements was carried out to support indication of the success of coating mercapto-silica on

Table 3 Parameters of magnetite calculated from XRD pattern

\begin{tabular}{lccccc}
\hline Magnetite & $\mathbf{2 \theta}\left({ }^{\circ}\right)$ & Intensity & $\mathbf{a}(\AA)$ & $\mathbf{d}_{\mathbf{3 1 1}}(\AA)$ & $\overline{\mathbf{D}}_{\text {XRD }}(\mathbf{n m})$ \\
\hline $\mathrm{C}-\mathrm{Fe}_{3} \mathrm{O}_{4}$ & 35.48 & 957 & 8.21 & 2.53 & 28.93 \\
$\mathrm{~m}-\mathrm{Fe}_{3} \mathrm{O}_{4}$ & 35.55 & 185 & 8.41 & 2.52 & 14.84 \\
$\mathrm{u}-\mathrm{Fe}_{3} \mathrm{O}_{4}$ & 35.62 & 274 & 8.31 & 2.52 & 14.21 \\
\hline
\end{tabular}

magnetite and the result is expressed in Table 5. It is observed that hydrogen is detected in magnetite and silica coated magnetite samples due to presence of water hydrated or silanol in the samples. Coating mercapto modified silica on magnetite is revealed by the presence of sulfur from thiol groups in both materials of magnetite coated with mercapto modified silica. The weight percentage ratio of $\mathrm{S}$ to $\mathrm{C}(\mathrm{S} / \mathrm{C})$ obtained $(0.77$ for $\mathrm{Fe}_{3} \mathrm{O}_{4}-\mathrm{SiO}_{2}-\mathrm{SH}(50: 50)$ and 0.99 for $\left.\mathrm{Fe}_{3} \mathrm{O}_{4}-\mathrm{SiO}_{2}-\mathrm{SH}\right)$ is comparable to the value of S/C for MPTMS calculated theoretically $(0.89)$. The component fraction represented as weight percentage of merapto-silica coated magnetite may be calculated based on the yield weight and elemental content of the samples. $\mathrm{Fe}_{3} \mathrm{O}_{4}-\mathrm{SiO}_{2}-\mathrm{SH}(50: 50)$ consists of

Table 4 Yield of coated magnetite materials before and after washing with deionized water and fraction of coated material

\begin{tabular}{|c|c|c|c|}
\hline \multirow[t]{2}{*}{ Product } & \multicolumn{2}{|c|}{ Weight (g) } & \multirow{2}{*}{$\begin{array}{c}\text { Weight } \\
\text { fraction } \\
\text { of } \\
\text { coated } \\
\text { material } \\
(\%)\end{array}$} \\
\hline & Before washing & After washing & \\
\hline $\mathrm{Fe}_{3} \mathrm{O}_{4}-\mathrm{SiO}_{2}$ & 1.84 & 0.70 & 28.57 \\
\hline $\mathrm{Fe}_{3} \mathrm{O}_{4}-\mathrm{SiO}_{2}-\mathrm{SH}(75 / 25)$ & 1.96 & 0.95 & 47.37 \\
\hline $\mathrm{Fe}_{3} \mathrm{O}_{4}-\mathrm{SiO}_{2}-\mathrm{SH}(50 / 50)$ & 1.52 & 0.91 & 45.05 \\
\hline $\mathrm{Fe}_{3} \mathrm{O}_{4}-\mathrm{SiO}_{2}-\mathrm{SH}(25 / 75)$ & 1.43 & 1.00 & 50.00 \\
\hline $\mathrm{Fe}_{3} \mathrm{O}_{4}-\mathrm{SH}$ & 1.17 & 1.17 & 57.27 \\
\hline
\end{tabular}


Table 5 Result of elemental analysis in magnetite samples

\begin{tabular}{lccc}
\hline Sample & \multicolumn{3}{c}{ Content of element (\%) } \\
\cline { 2 - 4 } & $\mathbf{C}$ & $\mathbf{H}$ & S \\
\hline $\mathrm{u}-\mathrm{Fe}_{3} \mathrm{O}_{4}$ & n.d & 0.41 & n.d \\
$\mathrm{Fe}_{3} \mathrm{O}_{4}-\mathrm{SiO}_{2}$ & n.d & 0.42 & n.d \\
$\mathrm{Fe}_{3} \mathrm{O}_{4}-\mathrm{SiO}_{2}-\mathrm{SH}(50: 50)$ & 5.49 & 1.38 & 4.20 \\
$\mathrm{Fe}_{3} \mathrm{O}_{4}-\mathrm{SH}$ & 13.21 & 2.64 & 13.15 \\
\hline
\end{tabular}

n.d: non detected.
54.05\% $\mathrm{Fe}_{3} \mathrm{O}_{4}, 30.87 \% \mathrm{SiO}_{2}$ and $15.08 \%$ mercaptopropyl groups. This result shows higher content of mercapto groups in comparison to the previous data $(2.57 \% \mathrm{~S})$ reported by Zhang et al. (2013). Additionally, calculation shows that $\mathrm{Fe}_{3} \mathrm{O}_{4}-\mathrm{SiO}_{2}-\mathrm{SH}(50: 50)$ and $\mathrm{Fe}_{3} \mathrm{O}_{4}-\mathrm{SH}$ contain mercapto groups of 1.31 and $4.11 \mathrm{mmol} / \mathrm{g}$ sample, respectively.

Coating mercapto-silica on magnetite results in the larger product weight and the increase is in-line with the amount of MPTMS added (Table 4). With constant weight of magnetite, the capability in mole to bond silicone from

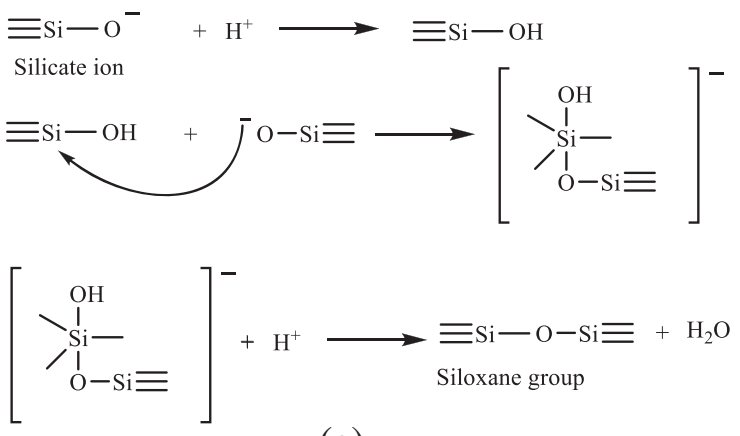

(a)
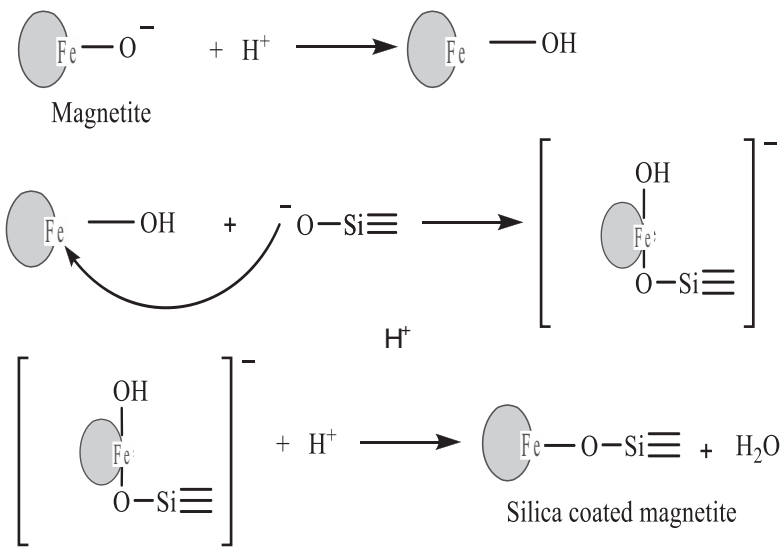

$\mathrm{H}^{+}$

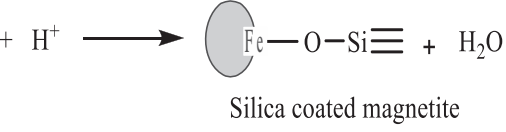

(b)

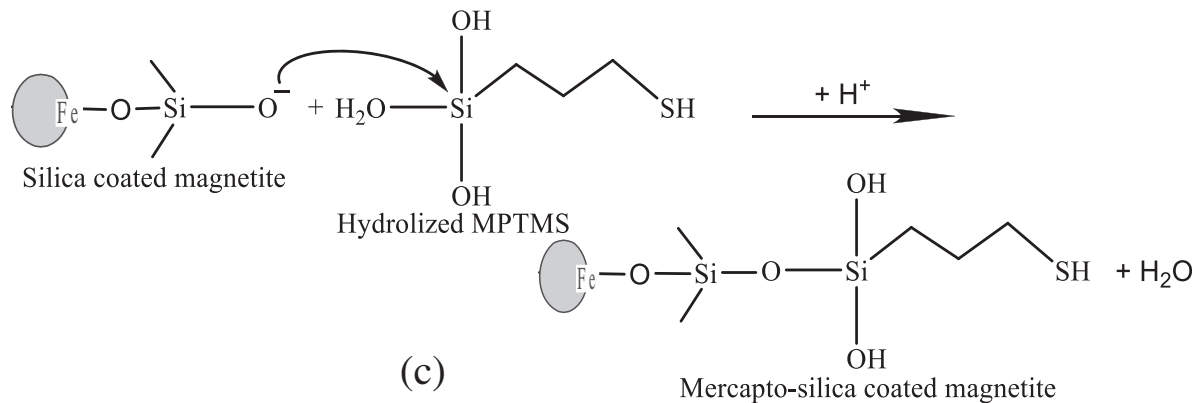

Figure 2 Formation model of $\mathrm{Fe}_{3} \mathrm{O}_{4}-\mathrm{SiO}_{2}$-SH from sodium silicate solution; (a) formation of $\mathrm{Si}-\mathrm{O}-\mathrm{Si}$, (b) formation of $\mathrm{Fe}-\mathrm{O}-\mathrm{Si}$ on magnetite surface, and (c) attachment of mercapto-propyl group on silica coated magnetite. 


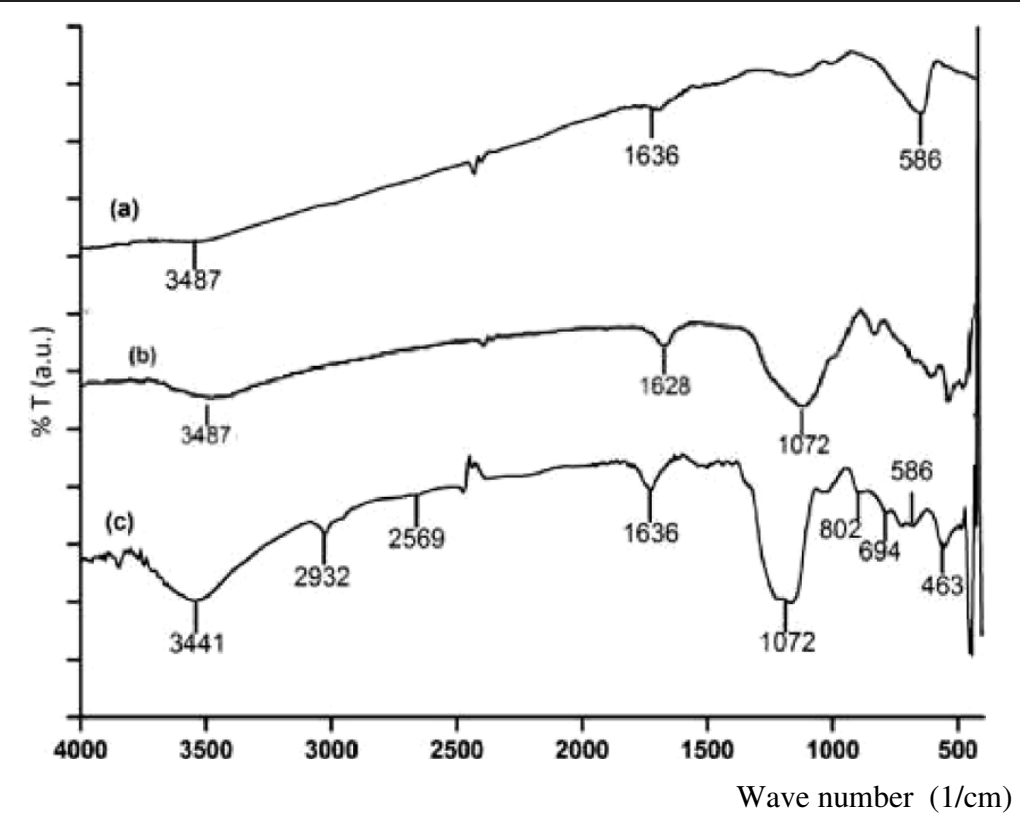

Figure 3 Infrared spectra of (a) $\mathrm{u}-\mathrm{Fe}_{3} \mathrm{O}_{4}$, (b) $\mathrm{Fe}_{3} \mathrm{O}_{4}-\mathrm{SiO}_{2}$, and (c) $\mathrm{Fe}_{3} \mathrm{O}_{4}-\mathrm{SiO}_{2}-\mathrm{SH}$ (50:50).

both sodium silicate and MPTMS is also constant. Since the molecular weight of MPTMS is larger than that of silica, inclining the MPTMS weight causes the increase of coated magnetite weight.

Before being coated, magnetite was acidified to form the active sites on the magnetite surface facilitating the interaction between the magnetite surface and reagent to be coated. Silica coated magnetite was carried out by adding $1 \mathrm{M} \mathrm{HCl}$ solution or $1 \mathrm{M} \mathrm{NH}_{4} \mathrm{OH}$ solution drop wise on a mixture of sodium silicate and magnetite to reach the $\mathrm{pH}$ of 7.0, and insoluble gel is formed. At $\mathrm{pH} 7.0$, silicate anion from sodium silicate solution may form siloxane bonds. At low $\mathrm{pH}$ (acidic condition) magnetite can be dissolved and the silica formed was converted from $\mathrm{SiO}_{2}$ to $\mathrm{Si}(\mathrm{OH})_{4}$. At higher $\mathrm{pH}$ (alkaline) the siloxane bonds are broken to produce silicate anions (Kalapathy et al. 2002).

Different from TEOS or TMOS, the use of sodium silicate as the precursor does not involve hydrolysis process. By adding acid, a part of silicate anions is protonated to form silicate acid driving force to form siloxane bonding with another silicate anion. Siloxane bond

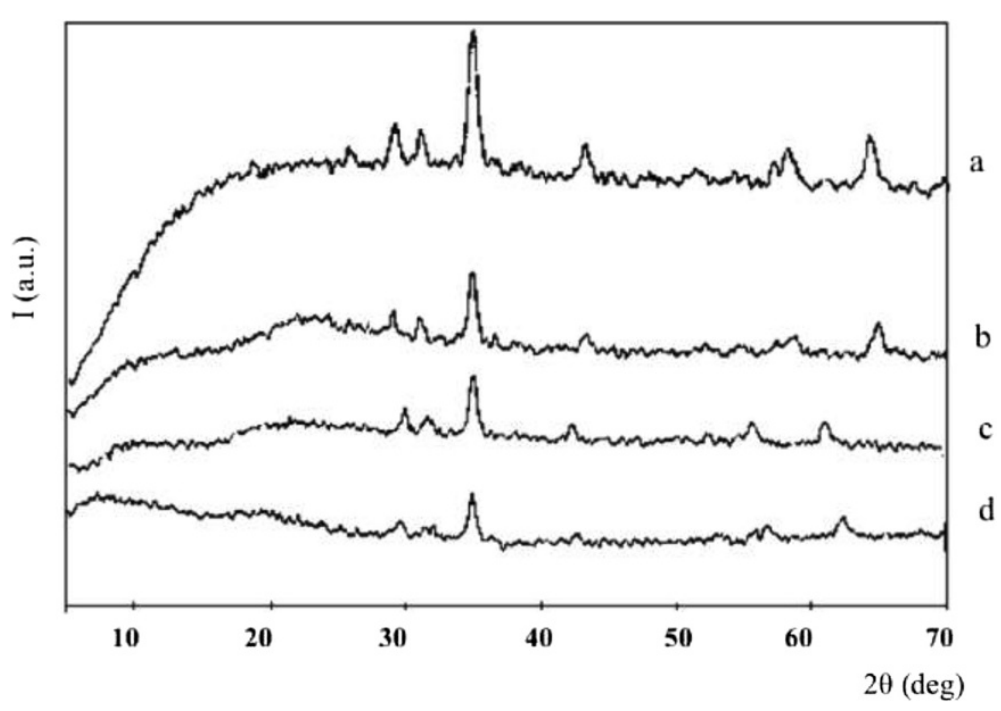

Figure 4 XRD patterns of magnetite materials; (a) $\mathrm{u}-\mathrm{Fe}_{3} \mathrm{O}_{4}$, (b) $\mathrm{Fe}_{3} \mathrm{O}_{4}-\mathrm{SiO}_{2}$, (c) $\mathrm{Fe}_{3} \mathrm{O}_{4}-\mathrm{SiO}_{2}-\mathrm{SH}$ (50:50) (c) and (d) $\mathrm{Fe}_{3} \mathrm{O}_{4}-\mathrm{SH}_{\text {. }}$ 
Table 6 Parameters of coated magnetite materials calculated from XRD pattern

\begin{tabular}{lccc}
\hline Material & $\mathbf{2 \theta}\left({ }^{\circ}\right)$ & Intensity & $\overline{\mathbf{D}}_{\text {XRD }}(\mathbf{n m})$ \\
\hline $\mathrm{u}-\mathrm{Fe}_{3} \mathrm{O}_{4}$ & 35.62 & 274 & 14.21 \\
$\mathrm{Fe}_{3} \mathrm{O}_{4}-\mathrm{SiO}_{2}$ & 35.43 & 126 & 25.12 \\
$\mathrm{Fe}_{3} \mathrm{O}_{4}-\mathrm{SiO}_{2}-\mathrm{SH}(50: 50)$ & 35.43 & 115 & 27.25 \\
$\mathrm{Fe}_{3} \mathrm{O}_{4}-\mathrm{SH}$ & 35.19 & 80 & 21.06 \\
\hline
\end{tabular}

formation leads to the oligomerization reaction (formation of silica network). Therefore, gel formation occurs due to condensation of silicate anion and acid, and the reaction may be expressed in Figure 2(a) (Sulastri et al. 2011).

Addition of $\mathrm{HCl}$ in coating magnetite leads to protonation of oxygen atom on magnetite giving to lower negative charge density on Fe atom. It makes easily to be attracted by electron pair of siloxy group $\left(\mathrm{Si}-\mathrm{O}^{-}\right)$from silicate anion to form Fe-O-Si group. The reaction of attachment of silica on magnetite can be modeled in Figure 2(b) (Durdureanu-Angheluta et al. 2008).
The presence of silane agent from MPTMS may involve the formation of siloxane bonding with silica bonded to magnetite and it leads to attachment of mercapto modified silica on magnetite. Attachment of mercaptopropyl groups on silica is initiated by hydrolysis of methoxy groups from MPTMS in basic solution to form silanol $(\mathrm{Si}-\mathrm{OH})$ groups and these groups may react with silicate anion coated on magnetite to form Fe-O-Si-O-Si- $\left(\mathrm{CH}_{2}\right)_{3}-\mathrm{SH}$ (Figure 2(c)).

\section{Functional groups of coated magnetite}

Analysis with infrared spectroscopy is aimed to identify the change of functional group presence due to coating of magnetite. IR spectra resulted from the measurement for three different magnetite materials is presented in Figure 3.

In FT-IR spectra of magnetite (Figure 3(a)) is observed an absorbance band at $586 \mathrm{~cm}^{-1}$ corresponding $\mathrm{Fe}-\mathrm{O}$ bond and it is attributed to formation of ferrite phase. Different from magnetite, FT-IR spectra of silica coated magnetite, $\mathrm{Fe}_{3} \mathrm{O}_{4}-\mathrm{SiO}_{2}$, (Figure $3(\mathrm{~b})$ ) shows pronounce

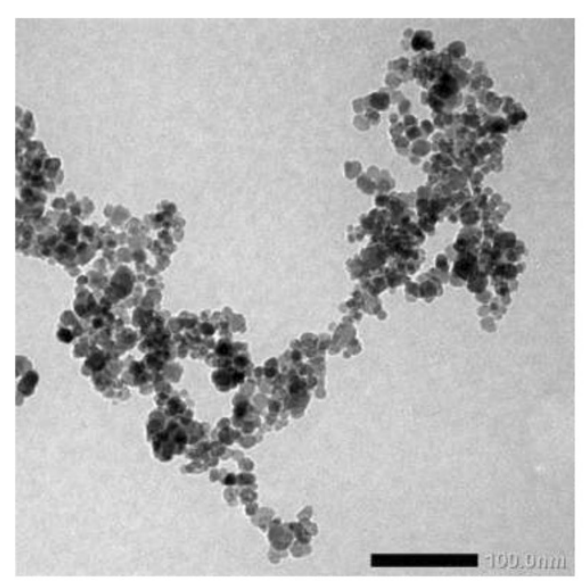

(a)

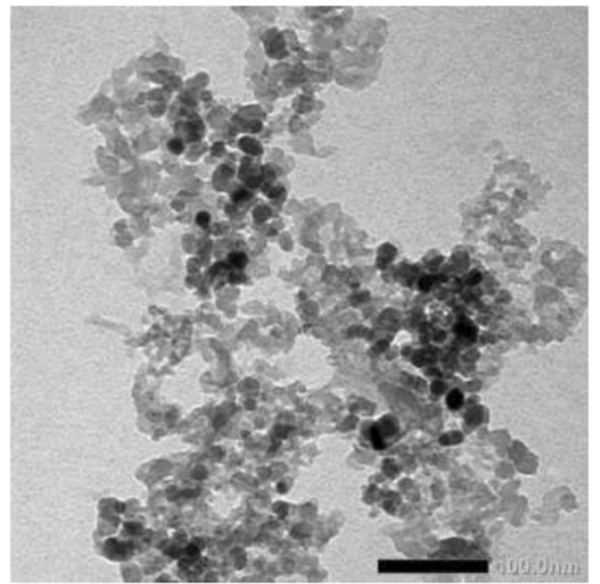

(c)

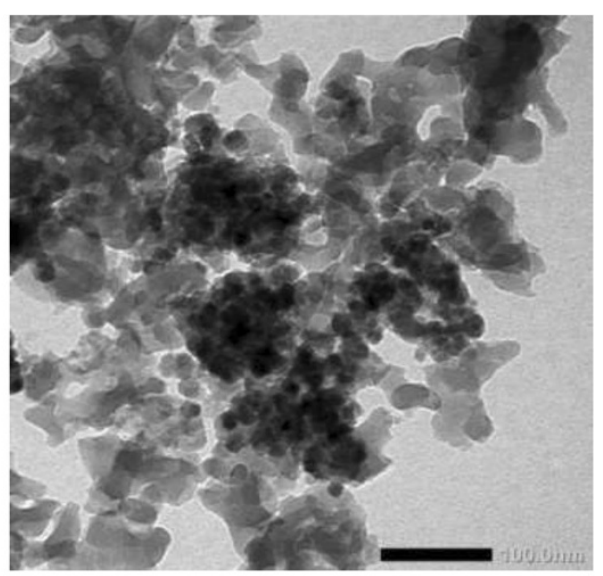

(b)

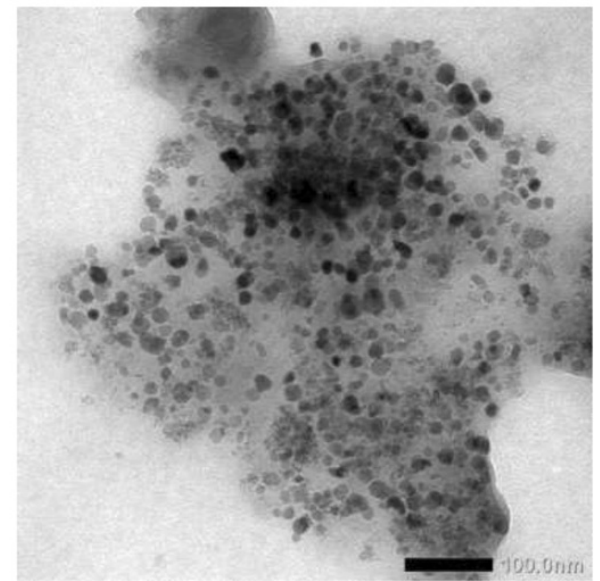

(d)

Figure 5 TEM image of magnetite materials; (a) u- $\mathrm{Fe}_{3} \mathrm{O}_{4}$, (b) $\mathrm{Fe}_{3} \mathrm{O}_{4}-\mathrm{SiO}_{2}$, (c) $\mathrm{Fe}_{3} \mathrm{O}_{4}-\mathrm{SiO}_{2}-\mathrm{SH}\left(50: 50\right.$ ), and (d) $\mathrm{Fe} \mathrm{O}_{4}-\mathrm{SH}$. 


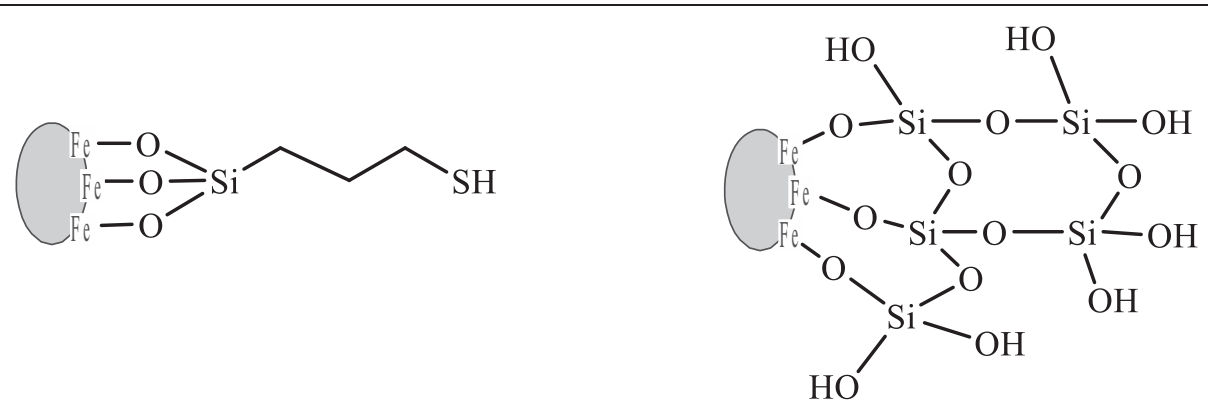

(a)

(b)<smiles>O[Si]1(O)O[Si]2(O)O[Si](O)(O)O[Si]3(O)O[Si](O)(O1)O[Si](O)(CCCS)O[Si](O)(O2)O3</smiles>

(c)

Figure 6 Structural model of magnetite materials; (a) $\mathrm{Fe}_{3} \mathrm{O}_{4}-\mathrm{SH}$, (b) $\mathrm{Fe}_{3} \mathrm{O}_{4}-\mathrm{SiO}_{2}$, and (c) $\mathrm{Fe}_{3} \mathrm{O}_{4}-\mathrm{SiO}_{2}-\mathrm{SH}$ (50:50).

changes, particularly at region of $1300-700 \mathrm{~cm}^{-1}$, indicating the presence of silica coating. The presence of silica coated on magnetite is shown with characteristic band at $463 \mathrm{~cm}^{-1}$ from bending vibration of $\mathrm{Si}-\mathrm{O}-\mathrm{Si}$. Asymmetric bending vibration corresponding to $\mathrm{Si}-\mathrm{O}-\mathrm{Si}$ bonding is revealed with absorbance band at $1072 \mathrm{~cm}^{-1}$. Absorbance bands in coated magnetite FT-IR spectra around 1628$1636 \mathrm{~cm}^{-1}$ and $3441-3487 \mathrm{~cm}^{-1}$ come from bending and stretching vibration, respectively, of $-\mathrm{OH}$ groups from both $\mathrm{Fe}-\mathrm{OH}$ and $\mathrm{Si}-\mathrm{OH}$. Stretching vibration of Si-O-H bonding results in an absorbance band at $960 \mathrm{~cm}^{-1}$. In FTIR spectra of magnetite coated only with silica, absorbance of $\mathrm{Si}-\mathrm{OH}$ vibration does not appear clearly due to overlap with broad band of stretching vibration from Si-O-Si.

In comparison to magnetite and silica coated magnetite, FT-IR spectra of mercapto-silica coated magnetite, $\mathrm{Fe}_{3} \mathrm{O}_{4}$ $\mathrm{SiO}_{2}-\mathrm{SH}(50: 50$ ), (Figure 3(c)) gives characteristic absorbance of propyl and mercapto groups from MPTMS. The $\mathrm{C}-\mathrm{H}$ bonding of propyl groups results in absorbance at

Table 7 BET Data

\begin{tabular}{|c|c|c|c|}
\hline Material & $\begin{array}{l}\text { Surface area } \\
\left(\mathrm{m}^{2} / \mathrm{g}\right)\end{array}$ & $\begin{array}{c}\text { Porous total } \\
\text { volume }\left(\mathrm{cm}^{3} / \mathrm{g}\right)\end{array}$ & $\begin{array}{c}\text { Porous diameter } \\
\text { average }(\AA)\end{array}$ \\
\hline $\mathrm{Fe}_{3} \mathrm{O}_{4}-\mathrm{SiO}_{2}$ & 82.24 & 0.42 & 101.09 \\
\hline $\begin{array}{l}\mathrm{Fe}_{3} \mathrm{O}_{4}-\mathrm{SiO}_{2}-\mathrm{SH} \\
(50: 50)\end{array}$ & 162.52 & 0.48 & 58.74 \\
\hline $\mathrm{Fe}_{3} \mathrm{O}_{4}-\mathrm{SH}$ & 3.42 & 0.02 & 108.94 \\
\hline
\end{tabular}

$2932 \mathrm{~cm}^{-1}$ corresponding to bending and asymmetric vibration of $\mathrm{C}-\mathrm{H}$. The presence of mercapto groups is identified by the appearance of bands at 694 and $879 \mathrm{~cm}^{-1}$ that can be assigned to asymmetric stretching of C-S and bending vibration of S-H. Weak bands at $2569 \mathrm{~cm}^{-1}$ in IR spectra of mercapto coated magnetite is additional proof of the presence of -SH groups.

\section{Structure of coated magnetite}

To effect of the sodium silicate to MPTMS mole ratio on the structure of the coated magnetite resulted, the coated magnetite samples were analyzed with XRD method and the result is expressed in Figure 4. It can be seen from Figure 4 that coating process does not change the peak position but the intensity, particularly for index [311], decreases with increasing the amount of MPTMS added. It means that coating process does not lead to change the crystallite structure but the presence of the mineral but reduces level. Addition of amorphous materials such as silica and MPTMS may cover the crystallite and lead to the peak intensity lower. The change of intensity and $\mathrm{D}_{\text {XRD }}$ quantitatively has been calculated and presented in Table 6.

Table 6 reveals larger crystallite size of coated magnetite in comparison to that of without coating one indicating that coating on the magnetite surface is proved. Magnetite coated only silica $\left(\mathrm{Fe}_{3} \mathrm{O}_{4}-\mathrm{SiO}_{2}\right)$ gives bigger crystallite size 


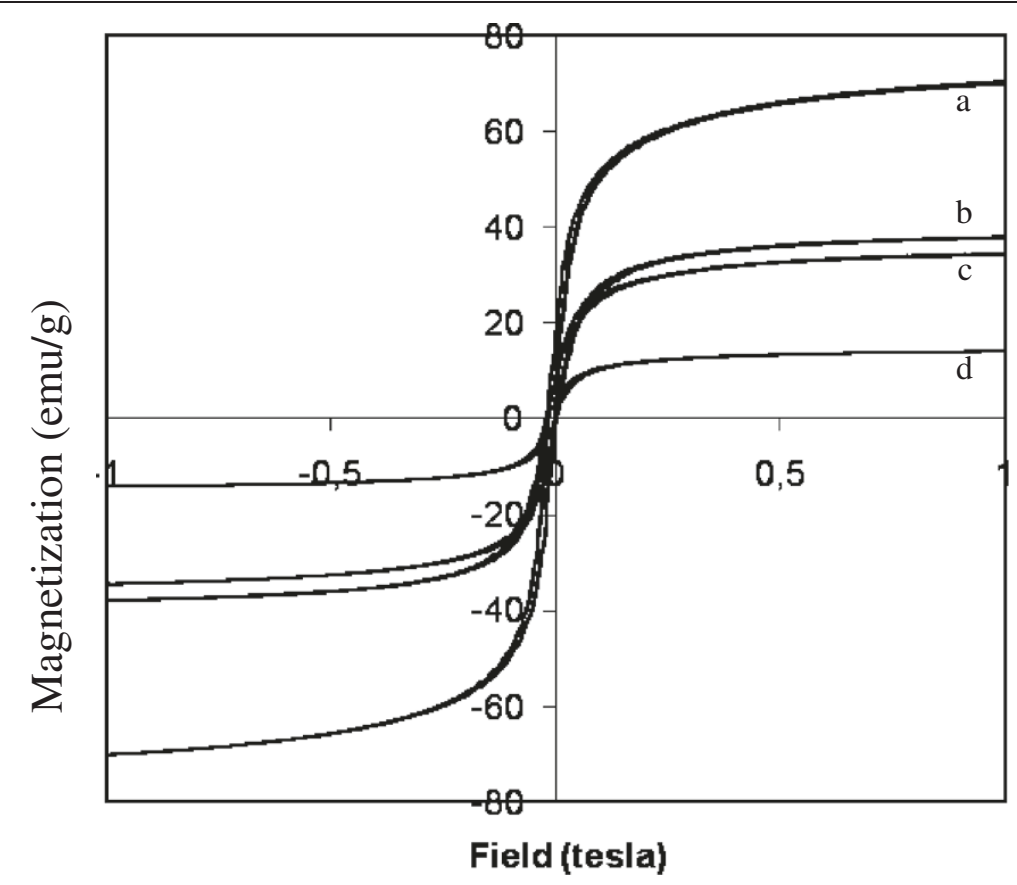

Figure 7 VSM hystheresis curve of magnetite materials; (a) $\mathrm{u}-\mathrm{Fe}_{3} \mathrm{O}_{4}$, (b) $\mathrm{Fe}_{3} \mathrm{O}_{4}-\mathrm{SH}$, (c) $\mathrm{Fe}_{3} \mathrm{O}_{4}-\mathrm{SiO}_{2}$, and (d) $\mathrm{Fe}_{3} \mathrm{O}_{4}-\mathrm{SiO} \mathrm{O}_{2}-\mathrm{SH}(50: 50$ ).

than that coated only MPTMS $\left(\mathrm{Fe}_{3} \mathrm{O}_{4}-\mathrm{SH}\right)$. It is probable due to the oligomerization of silica before coating on the magnetite surface. In contrast, the presence of mercapto propyl groups in MPTMS inhibits oligomerization reaction and result in the formation of thin one layer MPTMS coated magnetite. Combination coating of silica and MPTMS gives biggest crystallite size among the investigated samples. Oligomerization of silica combined with attachment of MPTMS on the silica is suspected as the factor affecting the crystallite size.

\section{Morphology of coated magnetite}

Morphology of magnetite was identified with transmission electron microscope (TEM) and the result is expressed in Figure 5. In Figure 5(a) is a TEM image of magnetite without coating that can be seen the presence of small black and gray spherical particles of magnetite. From the TEM image of mercapto and silica coated magnetite (Figure 5(b-d)) is showed that there are aggregates of bigger particles consisting of small back sphere as magnetite seed that are surrounded by gray shell of silica. This is another proof of the coating success. Due to the

Table 8 Magnetic parameters of magnetites

\begin{tabular}{lccc}
\hline Material & $\mathbf{M}_{\mathbf{s}}(\mathbf{e m u} / \mathbf{g})$ & $\mathbf{H}_{\mathbf{c}}\left(\times \mathbf{1 0}^{-\mathbf{2}}\right.$ Tesla) & $\left.\mathbf{M}_{\mathbf{r}} \mathbf{( e m u} \mathbf{g}\right)$ \\
\hline $\mathrm{u}-\mathrm{Fe}_{3} \mathrm{O}_{4}$ & 70.39 & 1.78 & 16.28 \\
$\mathrm{Fe}_{3} \mathrm{O}_{4}-\mathrm{SiO}_{2}$ & 34.26 & 1.85 & 7.89 \\
$\mathrm{Fe}_{3} \mathrm{O}_{4}-\mathrm{SiO}_{2}-\mathrm{SH}(50: 50)$ & 14.05 & 1.15 & 3.27 \\
$\mathrm{Fe}_{3} \mathrm{O}_{4}-\mathrm{SH}$ & 37.75 & 1.85 & 7.43 \\
\hline
\end{tabular}

aggregate formation, however, particle size is difficult to be estimated. However, qualitatively may be estimated from Figure 5 that the order of particle size is $\mathrm{u}-\mathrm{Fe}_{3} \mathrm{O}_{4}>\mathrm{Fe}_{3} \mathrm{O}_{4}$ $\mathrm{SiO}_{2}-\mathrm{SH}(50: 50)>\mathrm{Fe}_{3} \mathrm{O}_{4}-\mathrm{SiO}_{2}>\mathrm{Fe}_{3} \mathrm{O}_{4}-\mathrm{SH}$. Identification results support the reaction modelled in Figure 2 and the hypothetic structure of coated magnetite materials can be expressed in Figure 6.

\section{Porosity}

Another important character of magnetite is particle porosity including surface area and pore size that may be measured using BET analysis. The result of analysis is summarized in Table 7 revealing that surface area of coated magnetite increases with increasing particle size (Table 6). As described before, silica coated on magnetite may experience oligomerization reaction and exhibit porous layers outside of magnetite seed. In contrary magnetite coated only with MPTMS gives smallest surface area due to only one layer of MPTMS formed on the surface of magnetite. On magnetite coated with silica and MPTMS have the greatest particle size as well as highest surface area. Reaction between silica with MPTMS results in thicker coating on magnetite. Based on Table 7, the porous diameter average of all coated magnetite materials is higher than $20 \AA$ that can be categorized as mesoporous material.

\section{Magnetic property of coated magnetite}

The effect of magnetite coating on magnetic property may be evaluated from the data of analysis. This analysis 


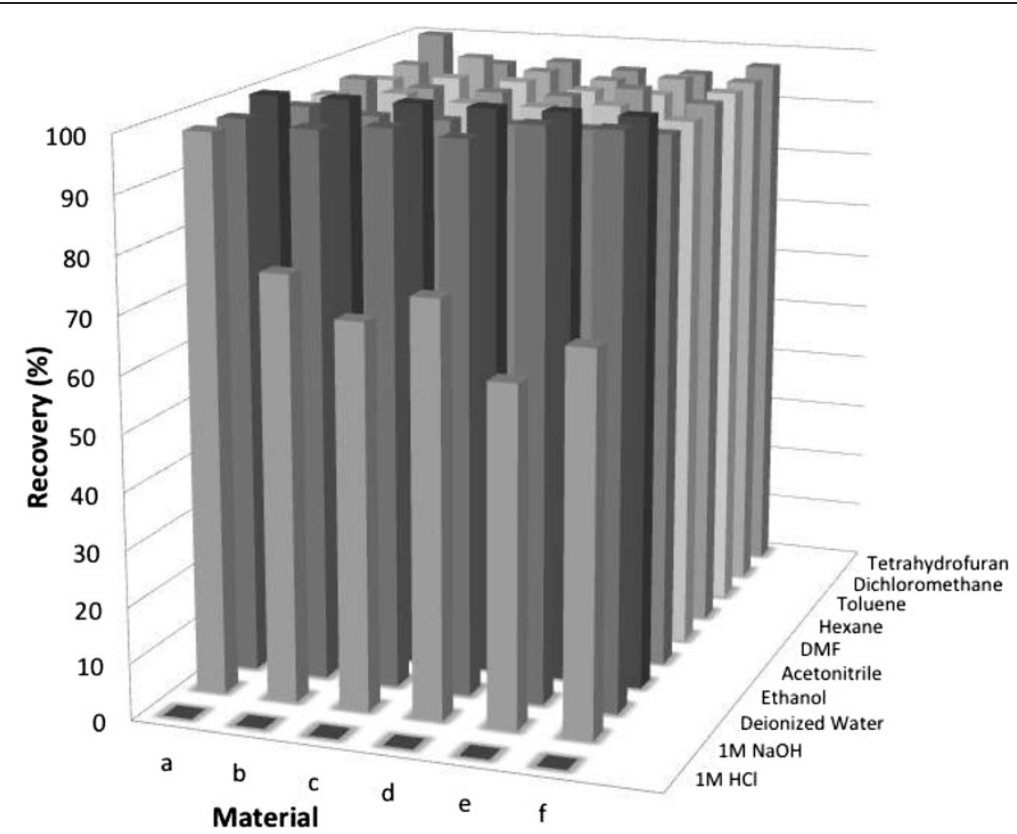

Figure 8 Recovery of (a) $\mathrm{u}-\mathrm{Fe}_{3} \mathrm{O}_{4}$, (b) $\mathrm{Fe}_{3} \mathrm{O}_{4}-\mathrm{SiO}_{2}$, (c) $\mathrm{Fe}_{3} \mathrm{O}_{4}-\mathrm{SiO}_{2}-\mathrm{SH}(75: 25)$, (d) $\mathrm{Fe}_{3} \mathrm{O}_{4}-\mathrm{SiO}_{2}-\mathrm{SH}\left(50: 50\right.$ ), (e) $\mathrm{Fe}_{3} \mathrm{O}_{4}-\mathrm{SiO}_{2}-\mathrm{SH}(25: 75)$ and (f) $\mathrm{Fe}_{3} \mathrm{O}_{4}-\mathrm{SH}$ by magnet after 10 times dispersion-recollection from various solvents.

utilizes a power of the external magnetic field to produce a hysteresis curve describing the magnetic properties of samples. This curve resulted from analysis of coated magnetite is expressed in Figure 7, and magnetic parameters including saturation field value $\left(\mathrm{M}_{\mathrm{s}}\right)$, coercivity field $\left(\mathrm{H}_{\mathrm{c}}\right)$ and permanent magnetization $\left(\mathrm{M}_{\mathrm{r}}\right)$ can be calculated and presented in Table 6 . The hysteresis curve represents the energy required for magnetization. From Figure 7 seems that all magnetite (coated and un-coated) give small curve area indicating low energy for magnetization and are classified as soft magnet. This assumption is supported by the low $\mathrm{H}_{\mathrm{c}}$ values of the samples. The value of $\mathrm{H}_{\mathrm{c}} \neq 0$ for uncoated and coated magnetites indicates ferrimagnetic properties of the samples. Similar results that coating decreases the energy of magnetization have been reported by previous researchers. Zhang et al. (2013) reported that coating magnetite with the same material (thiol-silica) reduces the maximum saturation magnetization from 55.05 to $20.14 \mathrm{emu} / \mathrm{g}$. Coating magnetite with amino-silica material leads to decrease of magnetization (Lin et al. 2011). It was explained that this decrease was ascribed to the contribution of the nonmagnetic $\mathrm{NH}_{2} / \mathrm{SiO}_{2}$ layer to the total mass of the particles.

From Table 8, based on the $\mathrm{M}_{\mathrm{s}}$ value, can be seen that coated magnetite gives lower magnetic property than without coated one. Magneticity of single layer coating (silica or MPTMS) is higher than that of double layer coating (silica and MPTMS). This phenomenon is consistent with the crystallite size in Table 6 . The increase of particle size leads to declining the magnetic property.

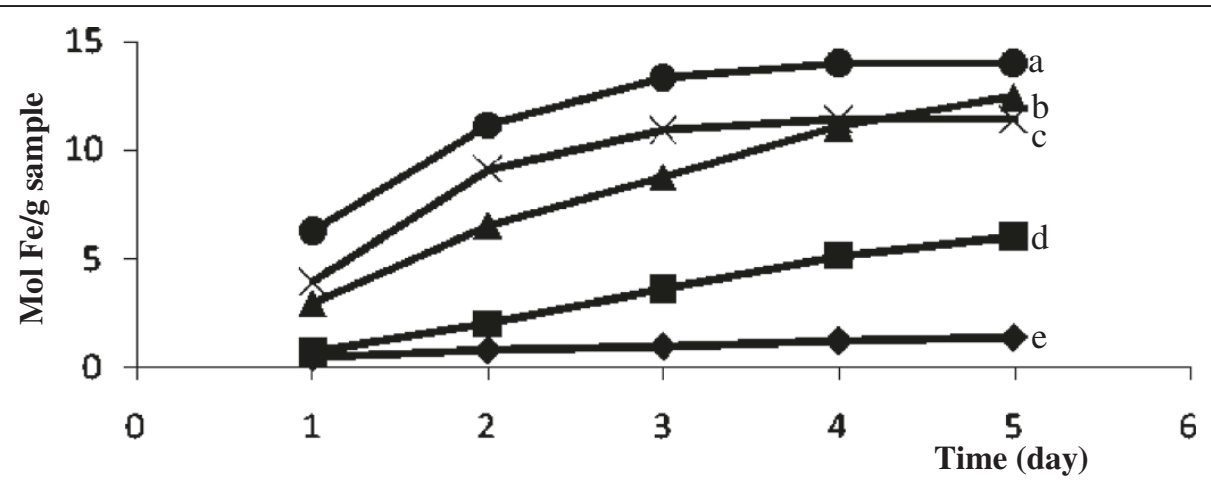

Figure 9 The amount of Fe dissolved in $2 \mathrm{M} \mathrm{HCl}$ within 5 days from magnetite materials; (a) $\mathrm{Fe}_{3} \mathrm{O}_{4}-\mathrm{SiO}_{2}-\mathrm{SH}_{(25: 75)}$, (b) $\mathrm{Fe}_{3} \mathrm{O}_{4}-\mathrm{SiO}_{2}-\mathrm{SH}$ (75:25), (c) $\mathrm{Fe}_{3} \mathrm{O}_{4}-\mathrm{SiO}_{2}-\mathrm{SH}(50: 50)$, (d) $\mathrm{Fe}_{3} \mathrm{O}_{4}-\mathrm{SiO}_{2}$ and (e) $\mathrm{Fe}_{3} \mathrm{O}_{4}-\mathrm{SH}$. 


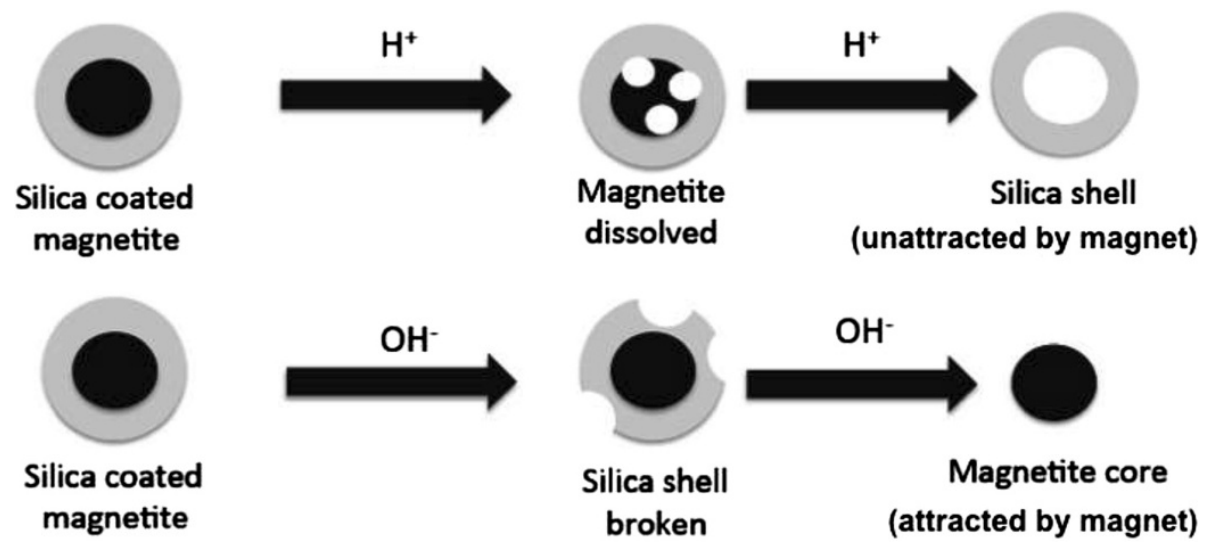

Figure 10 Dissolution model of silica coated magnetite material in acid solution and in base solution.

Large particle size results in low mobility and is difficult to be attracted by external magnetic field.

\section{Stability of coated magnetite toward various solvents}

One of objectives of coating is to protect magnetite from chemical reaction. In this work, we evaluated the effect of coating on the chemical stability of magnetite toward various solvents. Magnetite sample was mixed with various solvents for certain period and collected by using external magnet. Several solvents such as nonpolar solvents (hexane and toluene), polar aprotic solvents (dichloromethane and tetrahydrofurane) and polar solvents (deionized water and ethanol) were used in this experiment. In Figure 8 is shown that almost all of tested samples could be recovered from various types of solvents with different polarity even after 10 cycles of dispersion and recollection. There is no significant mass lost after recollection. It indicates that magnetite based materials resulted are relatively stable toward various solvents with different polarity. However, the different phenomena was observed when the magnetite materials were mixed with strong acidic or basic solution. As can be seen in Figure 8, all magnetite materials tested are not recollected at all using an external magnet when those are dissolved in $1 \mathrm{M} \mathrm{HCl}$ solution. In acidic solution magnetite is dissolved to form $\mathrm{Fe}^{2+} / \mathrm{Fe}^{3+}$ ions whereas undissolved silica based material that is not attracted with magnet and remains in the solution as suspension. However, the addition of $1 \mathrm{M} \mathrm{NaOH}$ leads to weight loss partly of the tested samples. It may be understood since $\mathrm{NaOH}$ solution is able to dissolve silica based silica to form silicate ion but not for magnetite which is stable in basic condition and recollected with an external magnet.

Additionally, the chemical stability was also evaluated based on the amount of Fe released to the solution after the magnetite materials were dispersed in $2 \mathrm{M} \mathrm{HCl} \mathrm{solu-}$ tion for 5 days and the result is presented in Figure 9. In comparison to other types of magnetites, Figure 9 shows that $\mathrm{Fe}_{3} \mathrm{O}_{4}-\mathrm{SH}$ is the most stable among the examined magnetites toward $\mathrm{HCl}$ solution. According to Lam et al. (2008), mercaptopropyl groups from MPTMS tend to not interact with proton; hence this coating is able to protect magnetite from acid. It is different from magnetite coated with silica where oxygen atom of silica may interact with proton that leads to weaken the siloxane bonding. Magnetite with double coating tends to have lower stability than that with single coating. It has not been understood the reason, however, probable due to the surface area effect. Magnetite with double coating $\left(\mathrm{Fe}_{3} \mathrm{O}_{4}-\mathrm{SiO}_{2}-\mathrm{SH}\right)$ gives largest surface area (Table 7$)$ so that effective to contact to proton and enhance the solubility of magnetite. Siloxane bond of silica on magnetite surface may react with $\mathrm{OH}^{-}$to form silicate, which is soluble in water. Further interaction of silica and $\mathrm{OH}^{-}$ breaks and dissolve silica coated and leaving magnetite core. Scheme of reaction between silica coated magnetite with acid or base is illustrated in Figure 10.

\section{Conclusions}

In this research, synthesis of mercapto-silica coated magnetite using sodium silicate solution prepared from rice hull ash as the silica source has been developed in aqueous solution through a simple and facile preparation approach called one pot process. This approach is rapid and does not require the addition of any surfactant to form mercapto-silica hybrid coated directly to magnetite. The presence of mercapto-silica on magnetite not only improves the stability of magnetite but also gives high potency as active sites effectively for heavy and hazardous metal ions. Material of magnetite coated with mercapto modified silica still shows magnetic property and can be attracted with external magnetic field. Therefore, it is expected that in the future mercapto-silica coated magnetite may be promoted as prospective adsorbent 
for simple separation of heavy metal ions from industrial waste water.

\section{Competing interest}

The authors declare that they have no competing interests.

\section{Authors' contributions}

NN carried out characterization and drafted the manuscript. NM carried out coating magnetite. SCWS studied preparation of magnetite and characterized products. BR and ST participated in presenting result and discussion, and help in drafting the manuscript. All authors read and approved the final manuscript.

\section{Acknowledgments}

This work was funded by the Directorate of Research and Community Services, Directorate General of Higher Education (DP2M-DIKTI), Indonesian Ministry of Education and Culture through Research Grant Kerjasama Luar Negeri dan Publikasi Internasional No.180/SP2H/PL/Dit.litabmas/IV/2013.

\section{Author details}

'Department of Chemistry, Faculty of Mathematics and Natural Sciences, Universitas Gadjah Mada, Yogyakarta 55281, Indonesia. ${ }^{2}$ Division of Environmental Science Development, Graduate School of Environmental Earth Science, Hokkaido University, Hokkaido, Japan. ${ }^{3}$ Division of Environmental Material Science, Graduate School of Environmental Earth Science, Hokkaido University, Hokkaido, Japan.

\section{Received: 7 February 2014 Accepted: 20 August 2014}

\section{Published: 11 September 2014}

\section{References}

Azmiyawati C, Nuryono, Narsito (2012) Adsorption of Mg(II) and Ca(II) on disulfonato-silica hybrid. Indo J Chem 12:223-228

Chang YC, Chen DH (2005) Preparation and adsorption properties of monodisperse chitosan-bound $\mathrm{Fe}_{3} \mathrm{O}_{4}$ magnetic nanoparticles for removal of Cu(II) ions. J Colloid Interface Sci 283:446-451

Daniel-da-Silva AL, Trindade T, Goodfellow BJ, Costa BFO, Correia RN, Gil AM (2007) In situ synthesis of magnetite nanoparticles in carrageenan gels. Biomacromolecules 8:2350-2357

Daniel-da-Silva AL, Loio R, Lopes-Da-Silva JA, Trindade T, Goodfellow BJ, Gil AM (2008) Effects of magnetite nanoparticles on the thermorheological properties of carrageenan hydrogels. J Colloid Interface Sci 324:205-211

Durdureanu-Angheluta A, Ardeleanu R, Pinteala M, Harabagiu V, Chiriac H, Simionescu BC (2008) Silane covered magnetite particles, preparation and characterization. Dig J Nanomater Bios 3:33-40

Hai B, Wu J, Chen X, Protasiewicz JD, Scherson DA (2005) Metal-ion adsorption on carboxyl-bearing self-assembled monolayers covalently bound to magnetic nanoparticles. Langmuir 21:3104-3105

Hong RY, Feng B, Chen LL, Liu GH, Li HZ, Zheng Y, Wei DG (2008) Synthesis, characterization and MRI application of dextran-coated $\mathrm{Fe}_{3} \mathrm{O}_{4}$ magnetic nanoparticles. Biochem Eng J 42:290-300

Hu J, Chen G, Lo IMC (2005) Removal and recovery of Cr(VI) from wastewater by maghemite nanoparticles. Water Res 39:4528-4536

Kalapathy U, Proctor A, Schultz J (2002) An improved method for production of silica from rice hull ash. Bioresour Technol 85:285-289

Lam KF, Fong CM, Yeung KL, Mackay G (2008) Selective adsorption of gold from complex mixture using mesoporous adsorbents. Chem Eng J 145:185-195

Li FB, Li XZ, Liu CS, Liu TX (2007) Effect of alumina on photocatalytic activity of iron oxides for bisphenol a degradation. J Hazard Mater 149:199-207

Li H, Li Z, Liu T, Xiao X, Peng Z, Deng L (2008) A novel technology for biosorption and recovery hexavalent chromium in wastewater by biofunctional magnetic beads. Bioresour Technol 99:6271-6279

Lin Y, Chen H, Lin K, Chen B, Chiou C (2011) Application of magnetic particles modified with amino groups to adsorb copper ions in aqueous solution. J Environ Sci 23:44-50

Liu JF, Zhao ZS, Jiang GB (2008) Coating $\mathrm{Fe}_{3} \mathrm{O}_{4}$ magnetic nanoparticles with humic acid for high efficient removal of heavy metals in water. Environ Sci Technol 42:6949-6954

Mahmoudi M, Sant S, Wang B, Laurent S, Sen T (2011) Superparamagnetic iron oxide nanoparticles (SPIONs): development, surface modification and applications in chemotherapy. Adv Drug Delivery Rev 63:24-46
Ngomsik AF, Bee A, Siaugue JM, Cabuil V, Cote G (2006) Nickel adsorption by magnetic alginate microcapsules containing an extractant. Water Res 40:1848-1856

Pang SC, Kho SY, Chin SF (2012) Fabrication of magnetite/silica/titania core-shell nanoparticles. J Nanomater 2012:1-6

Rebolledo AF, Fuertes AB, Gonzalez-Carreno T, Sevilla M, Valdes-Solis T, Tartaj P (2008) Signatures of clustering in superparamagnetic colloidal nanocomposites of an inorganic and hybrid nature. Small 4:254-261

Ren Y, Wei X, Zhang M (2008) Adsorption character for removal Cu(II) by magnetic $\mathrm{Cu}(\mathrm{II})$ ion imprinted composite adsorbent. J Hazard Mater 158:14-22

Sakti SCW, Siswanta D, Nuryono (2013) Adsorption of gold(III) on ionic imprinted amino-silica hybrid prepared from rice hull ash. Pure Appl Chem 85:211-223

Shishehbore MR, Afkhami A, Bagheri H (2011) Salicylic acid functionalized silica-coated magnetite nanoparticles for solid phase extraction and preconcentration of some heavy metal ions from various real samples. Chem Cent J 5:41-51

Sulastri S, Nuryono, Kartini I, Kunarti ES (2011) Adsorption of calcium(II), lead(II) and silver(I) on sulfonato-silica hybrid prepared from rice hull ash. Indo J Chem 11:273-278

Yang RT (2003) Adsorbents: fundamen tals and applications. John Wiley \& Sons, USA

Yang D, Hu J, Fu S (2009) Controlled synthesis of magnetite-silica nanocomposites via a seeded sol-gel approach. J Phys Chem 113:7646-7651

Yantasee W, Warner CL, Sangvanich T (2007) Removal of heavy metals from aqueous systems with thiol functionalized superparamagnetic nanoparticles. Environ Sci Technol 41:5114-5119

Yavuz CT, Yu WW, Prakash A (2006) Low-field magnetic separation of monodisperse $\mathrm{Fe}_{3} \mathrm{O}_{4}$ nanocrystals. Science 314:964-967

Zhang Y, Xu Q, Zhang S, Liu J, Zhou J, Xu H, Xiao H, Li J (2013) Preparation of thiol-modified $\mathrm{Fe}_{3} \mathrm{O}_{4} @ \mathrm{SiO}$ 2nanoparticles and their application for gold recovery from dilute solution. Sep Purif Technol 116:391-397

Zhou YT, Branford White C, Nie HL, Zhu LM (2009) Adsorption mechanism of $\mathrm{Cu}^{2+}$ from aqueous solution by chitosan-coated magnetic nanoparticles modified with á- ketoglutaric acid. Colloids Surf B 74:244-252

doi:10.1186/2193-1801-3-515

Cite this article as: Nuryono et al:: Coating of magnetite with mercapto modified rice hull ash silica in a one-pot process. SpringerPlus 2014 3:515.

\section{Submit your manuscript to a SpringerOpen ${ }^{\odot}$ journal and benefit from:}

- Convenient online submission

- Rigorous peer review

- Immediate publication on acceptance

- Open access: articles freely available online

- High visibility within the field

- Retaining the copyright to your article

Submit your next manuscript at $\gg$ springeropen.com 